\title{
QUANTITATIVE CHARACTERISTICS OF FRUITS AND SEEDS OF Pouteria pachycarpa PIRES - SAPOTACEAE ${ }^{1}$
}

\author{
ENIELDAVIDCRUZ²
}

\begin{abstract}
Pouteria pachycarpa is a tree species, found in the Brazilian Amazon and Bolivia whose wood has been exploited from the native forest. The present research describes the quantitative characteristics of fruits and seeds and quantifies the seed germination of this species. The fruit and seed color were characterized and measurements taken of the mass, length, diameter and number of seeds per fruit, the seed length, width and thickness, the germination percentage, abnormal seedlings and dead seeds. Sowing was carried out on a substrate containing sand and sawdust (1:1), in four replications of 50 seeds. The predominant fruit and seed colors were vivid yellowish orange (9YR) and dark grayish brown (6YR), respectively. Fruit mass, length and diameter ranged from 37.7 to $192.4 \mathrm{~g}, 41.3$ to $87.3 \mathrm{~mm}$ and 39.7 to $71.7 \mathrm{~mm}$, respectively. Fruits had from two to seven seeds, and $42.6 \%$ were damaged by insects. Seed length, width and thickness ranged from 22.4 to $35.2 \mathrm{~mm}, 9.7$ to $15.5 \mathrm{~mm}$ and 5.5 to $10.8 \mathrm{~mm}$, respectively. Seedling emergence began 18 days after sowing. Maximum germination, $86 \%$, was recorded 33 days after sowing. The germination curve was sigmoid, similar to the majority of species. The percentage of abnormal seedlings and dead seeds were $3 \%$ and $11 \%$, respectively. Both fruits and seeds show great variation in quantitative characteristics and the germination is slow and non-uniform.
\end{abstract}

Index terms: goiabão, physical characteristics, germination.

\section{CARACTERÍSTICAS QUANTITATIVAS DE FRUTOS E SEMENTES DE Pouteria pachycarpa Pires - SAPOTACEAE}

RESUMO - Pouteria pachycarpa Pires é uma espécie arbórea, encontrada na Amazônia brasileira e boliviana, cuja madeira tem múltiplos usos, sendo extraída de floresta nativa. O trabalho descreve as características físicas de frutos e sementes e quantifica a germinação de sementes de goiabão. Determinou-se a coloração de frutos e sementes, o peso, o comprimento e o diâmetro dos frutos e o número de sementes por fruto, o comprimento, a largura e a espessura das sementes, a porcentagem de germinação, de plântulas anormais e de sementes mortas. A semeadura ocorreu em substrato de areia e serragem (1:1), com quatro repetições de 50 sementes. A cor predominante nos frutos foi laranja-amarela-escura (9YR) e nas sementes, marron-acinzentada-escura (6YR). A massa, o comprimento e o diâmetro dos frutos variaram de 37,7 a 192,4g, de 41,3 a 87,3mm e de 39,7 a 71,7mm, respectivamente. Os frutos apresentaram de duas a sete sementes, com alta (42,6\%) porcentagem de sementes danificadas por insetos. O comprimento, a largura e a espessura das sementes variaram de 22,4 a 35,2mm, de 9,7 a 15,5mm e de 5,5 a 10,8mm, respectivamente. A emergência das plântulas iniciou-se no $18^{\circ}$ dia após a semeadura, atingindo a germinação máxima de $86 \%$, aos 33 dias. A porcentagem de plântulas anormais foi de $3 \%$ e de sementes mortas de $11 \%$. Frutos e sementes de goiabão apresentam grandes variações nas suas características quantitativas e a germinação é lenta e desuniforme.

Termos para indexação: goiabão, características físicas, germinação.

\footnotetext{
${ }^{1}$ Submetido em 16/08/2004. Aceito para publicação em 01/07/2005.
}

\footnotetext{
2 Eng. agrônomo, MSc., Embrapa Amazônia Oriental, Cx. Postal 48, 66017970, Belém, PA, Brasil. eniel@cpatu.embrapa.br
} 


\section{INTRODUCTION}

The lack of knowledge about wood species, along with extractive exploitation, has limited the conservation of the genetic resources and consequently the biodiversity. Edwards (2000) reveals that forest tree seed biology remains poorly studied for many species.

Although the Amazonian forest has high biological diversity the knowledge about its species is empiric (Ribeiro et al., 1999). In this region, 350 wood species have been exploited (Martini et al., 1998). Among the exploited species is Pouteria pachycarpa Pires, locally known as "goiabão", "abiurana-casca-grossa”, "abiurana-goiaba” (Camargos et al., 1996; Souza et al., 1997).

P. pachycarpa is a tree species that occurs in the Brazilian Amazon and Bolivia, and may grow up to $35 \mathrm{~m}$ height (Pires e Koury, 1958; Loureiro et al., 1997). Its wood is used to make furniture, decorative household, sliced veneers, civil construction, parquet flooring, paneling and others (Souza et al., 1997).

Although this species has been exploited since 1990 (Aimex, 1998), there is virtually no information about the characteristics of its fruits and seeds, as well as about the seed germination process.

According to Vázquez-Yanes e Aréchiga (1996), the amplification of the knowledge about wood species is a requirement for their use in commercial plantation and agroforestry systems. Therefore, the objective of this study was to determine the quantitative characteristics of fruits and seeds and quantify the seed germination of P. pachycarpa.

\section{MATERIAL AND METHODS}

Mature fruits of Pouteria pachycarpa Pires were collected from 15 trees after falling on the soil, in a native forest area, in the States of Rondônia to Pará $\left(04^{\circ} 32^{\prime} 20^{\prime \prime S}\right.$ and $\left.48^{\circ} 12^{`} 02^{\prime \prime W}\right)$, during the rainy season, in March 2001. The fruits were transported in bags to Embrapa Amazônia Oriental, in Belém - Pa, where the study was carried out immediately.

It was determined the color of fruits and seeds according to the Standard Color Chart (Japan Color Institute, 1997) and the weight, length and diameter in sample of 230 fruits, through electronic balance and digital caliper.

After seeds extraction from the fruits, they were washed in running water, during 30 minutes to remove the mucilage that covered the seeds. After that, the seeds were left to dry in the shade 18 hours at environmental local conditions (minimum and maximum temperature were $22.9^{\circ} \mathrm{C}$ and $33.6^{\circ} \mathrm{C}$, while minimum and maximum relative humidity were $79 \%$ and $89 \%$, respectively). Following that, it was quantified the percentage of complete seeds, empty seeds and seeds damaged by insects (seeds having holes caused by insects or having larva in them) in a sample of 998 units; the length, width and thickness of seeds, in a sample of 100 units; the mass and volume by eight replications of 100 units; and the moisture of the seeds by eight replications of five units. The length was the distance between the basal and apical parts of the seed, while the width and thickness were measured at the intermediate part of the seeds according to Cruz e Carvalho (2003). The volume was quantified through graduated measuring cylinder with capacity of $500 \mathrm{~cm}^{3}$. The seed moisture was quantified in a oven with temperature of $105 \pm 3^{\circ} \mathrm{C}$ during 24 hours, according to Brazil (1992) and the result was expressed as percentage of water content (fresh weight basis).

Sowing was carried out at $1.0 \mathrm{~cm}$ of depth in plastic recipient with a substrate containing sand and sawdust (1:1), previously sterilized in hot water $\left(100^{\circ} \mathrm{C}\right)$ during two hours. The substrate remained in the laboratory under local conditions of temperature and relative humidity, irrigated every two days. The germination, evaluated on four replications of 50 seeds, was quantified daily. It was considered as germinated seed when it showed the first pair of definitive leaves, with seedling having its essential parts completely developed and healthy. It was also identified the type of germination and seedling, according to Duke e Polhill (1981), the percentage of abnormal seedling and dead seeds, the number of days to begin the germination, i.e., the number of elapsed days from sowing until germination of the first seed, and the mean time of germination according to Edmond e Drapala (1965).

The biometrics data were analyzed through frequency distribution and the estimation of the size intervals class was adapted from Beiguelman (1991). The correlation analysis between characteristics of fruits and seeds and the graphical output were carried out by the Statistical for Windows software (Statsoft, 1998).

\section{RESULTS AND DISCUSSION}

The predominant color on fruits was vivid yellowish orange (9YR), although it has been observed that some fruits showed dark yellow green (5GY) color, like the color reported by Van Roosmalen e Garcia (2000) in others species of Pouteria Aubl. The color of seeds was dark grayish brown (6YR). Fruits of $P$. pachycarpa were slightly oblong (Figure 
1A), with mass, length and diameter ranging from 37.7 to 192.4g, 41.3 to $87.3 \mathrm{~mm}$ and 39.7 to $71.7 \mathrm{~mm}$, respectively, predominating values between 69.1 to $103.0 \mathrm{~g}, 59.1$ to $71.0 \mathrm{~mm}$ and 51.1 to $59.0 \mathrm{~mm}$, of mass, length and diameter, respectively (Table 1). The majority of fruits showed mass larger than $P$. anomala (Pires) T.D. Penn. (Van Roosmalen e Garcia, 2000) and smaller than observed in P. pariry (Ducke) Baehni by Cavalcante (1991). The length and diameter of fruits were similar to P. deliciosa T.D. Penn., P. guianensis Aubl., P. macrocarpa (Mart.) D. Dietr., P. manaosensis (Aubrév. e Pellegr.) T.D. Penn., P. venosa subesp. amazonica (Mart.) Baehni and P. virescens Baehni, observed by Van Roosmalen e Garcia (2000), however smaller than values observed in $P$. speciosa (Ducke) Baehni by Cavalcante (1991). The number of seeds per fruit varied from two to seven, but the most fruits had five seeds. The percentage of complete seeds, empty seeds and seeds damaged by insects was 55.5, 1.9 and $42.6 \%$ (Table 2). Similar variability on the number of seeds per fruit was observed by Cavalcante (1991) in $P$. caimito (Ruiz e Pav.) Radlk., but with smaller amplitude. Van Roosmalen e Garcia (2000) also report variability on the number of seed per fruit in other species of Pouteria, but the predominance was a single seed.

The mass and volume of seeds with moisture content of
$42.6 \%$, were $148.9 \mathrm{~g}$ and $250.6 \mathrm{~cm}^{3}$. In general, seed mass is influenced by the number of seeds produced by the plant and this fact was also observed in $P$. pachycarpa, which seeds showed a mass $50 \%$ smaller than $P$. caimito and the number of seeds per fruit was 56\% higher (Carvalho et al., 1998). Seeds were oblong (Figure 1B) with length, width and thickness ranging from 22.4 to $35.2 \mathrm{~mm}, 9.7$ to $15.5 \mathrm{~mm}$ and 5.5 to $10.8 \mathrm{~mm}$, respectively, predominating values between 27.1 to $31.0 \mathrm{~mm}, 11.7$ to $13.4 \mathrm{~mm}$ and 7.9 to $8.7 \mathrm{~mm}$, of length, width and thickness, respectively (Table 3). According to Van Roosmalen e Garcia (2000), P. atabapoensis (Aubrév.) T.D. Penn., P. bilocularis (H. Winkl.) Baehni, P. cuspidata subesp. robusta (A. DC.) Baehni, P. ephedrantha (A. DC.) Baehni, P. laevigata (Martius) Radlkofer, P. macrocarpa (Mart.) Dietri., P. manguieri (Aubrév.) T.D. Penn., P. oblanceolata Pires, P. macrophylla (Lam.) Eyma, P. putamenovi T.D. Penn., P. ramiflora (Mart.) Radlk., P. rodriguesiana Pires e T.D. Penn. and $P$. trilocularis Cronquist, have length, width and thickness similar to the ones observed in $P$. pachycarpa.

It was observed significant correlation between the majority of the studied characteristics (Table 4). Larger positive values were observed between mass and diameter of fruits and smaller between length of fruits and the number of

TABLE 1. Quantitative characteristics of Pouteria pachycarpa Pires fruits.

\begin{tabular}{|c|c|c|c|c|c|}
\hline \multicolumn{2}{|c|}{ Weight (g) } & \multicolumn{2}{|c|}{ Length $(\mathrm{mm})$} & \multicolumn{2}{|c|}{ Diameter (mm) } \\
\hline Class interval & Frequency (\%) & Class interval & Frequency $(\%)$ & Class interval & Frequency \%) \\
\hline$<52.1$ & 2 & $<47.1$ & 2 & $<43.1$ & 2 \\
\hline $52.1-69.0$ & 12 & $47.1-53.0$ & 5 & $43.1-47.0$ & 4 \\
\hline $69.1-86.0$ & 33 & $53.1-59.0$ & 11 & $47.1-51.0$ & 10 \\
\hline $86.1-103.0$ & 24 & $59.1-65.0$ & 42 & $51.1-55.0$ & 33 \\
\hline $103.1-120.0$ & 15 & $65.1-71.0$ & 20 & $55.1-59.0$ & 31 \\
\hline $120.1-137.0$ & 9 & $71.1-77.0$ & 17 & $59.1-63.0$ & 11 \\
\hline $137.1-154.0$ & 3 & $77.1-83.0$ & 2 & $63.1-67.0$ & 6 \\
\hline$>154.0$ & 2 & $>83.0$ & 1 & $>67.0$ & 3 \\
\hline
\end{tabular}

TABLE 2. Minimum, maximum and mean values obtained on the characterization of Pouteria pachycarpa Pires fruits and seeds.

\begin{tabular}{lccc}
\hline \multicolumn{1}{c}{ Variable } & Minimum & Maximum & Mean $^{1}$ \\
\hline Seeds per fruit (number) & 2 & 7 & $4.3 \pm 0.9$ \\
Mass of 100 seeds $(\mathrm{g})$ & 142.3 & 154.7 & $148.9 \pm 4.5$ \\
Volume of 100 seeds $\left(\mathrm{cm}^{3}\right)$ & 225.0 & 260.0 & $250.6 \pm 11.2$ \\
Complete seeds $(\%)$ & - & - & 55.5 \\
Seeds damaged by insects (\%) & - & - & 42.6 \\
Empty seeds (\%) & - & - & 1.9 \\
\hline
\end{tabular}

${ }^{1}$ Values represent means and standard deviation for seeds with moisture of $46.2 \%$ complete seeds, and negative value between number of complete seeds and number of damaged seeds.

The germination was epigeal and the seedling was phanerocotylar. This was also observed by Carvalho et al. (1998) in P. caimito, although Ducke (1965) report hypogeal germination in other species of Sapotaceae. The germinative process began on the $18^{\text {th }}$ day after sowing and the maximum daily germination of $24 \%$ was obtained on the $25^{\text {th }}$ (Figure 2A). Significant increments on germination were observed until the $28^{\text {th }}$ day after sowing with $82 \%$ (Figure 2B). After 



FIGURE 1. Fruits (A) and seeds (B) of Pouteria pachycarpa. Photos: José Edmar Urano de Carvalho.

TABLE 3. Quantitative characteristics of Pouteria pachycarpa Pires seeds.

\begin{tabular}{|c|c|c|c|c|c|}
\hline \multicolumn{2}{|c|}{ Length ( $\mathrm{mm})$} & \multicolumn{2}{|c|}{ Width (mm) } & \multicolumn{2}{|c|}{ Thickness (mm) } \\
\hline Class interval & Frequency (\%) & Class interval & Frequency (\%) & Class interval & Frequency \%) \\
\hline$<23.1$ & 2 & $<11.1$ & 7 & $<7.6$ & 10 \\
\hline $23.1-25.0$ & 5 & $11.1-11.6$ & 10 & $7.6-7.8$ & 13 \\
\hline $25.1-27.0$ & 15 & $11.7-12.2$ & 14 & $7.9-8.1$ & 16 \\
\hline $27.1-29.0$ & 44 & $12.3-12.8$ & 24 & $8.2-8.4$ & 17 \\
\hline $29.1-31.0$ & 23 & $12.9-13.4$ & 22 & $8.5-8.7$ & 18 \\
\hline $31.1-33.0$ & 6 & $13.5-14.0$ & 12 & $8.8-9.0$ & 15 \\
\hline $33.1-35.0$ & 4 & $14.1-14.6$ & 7 & $9.1-9.3$ & 7 \\
\hline$>35.0$ & 1 & $>14.6$ & 4 & $>9.3$ & 4 \\
\hline
\end{tabular}

the $28^{\text {th }}$ day, the increments were reduced and at the final of evaluation on the $33^{\text {rd }}$, the total germination was $86 \%$, smaller than rate reported in P. sapota (Jacq.) H.E. Moore e Stearan
(Ricker et al., 2000). The germination curve was a sigmoid model, which is the same standard model for the majority of the species (Czabactor, 1962; Tipton, 1984). Germination 
TABLE 4. Linear correlation coefficient among mass (M), length (L) and diameter (D) of fruits, total number of seeds per fruit (TNS), number of complete seeds (NCS), number of empty seeds (NES), number of seeds damaged by insects (NSD) of Pouteria pachycarpa Pires.

\begin{tabular}{ccccccc}
\hline Variables & $\mathrm{L}$ & $\mathrm{D}$ & $\mathrm{TNS}$ & $\mathrm{NCS}$ & $\mathrm{NES}$ & $\mathrm{NSD}$ \\
\hline $\mathrm{M}$ & $0.66^{* *}$ & $0.90^{* *}$ & $0.15^{*}$ & $0.17^{*}$ & $-0.15^{*}$ & $-0.14^{*}$ \\
$\mathrm{~L}$ & & $0.52 * *$ & $0.13^{\mathrm{NS}}$ & $0.01^{\mathrm{NS}}$ & $-0.27^{* *}$ & $0.06^{\mathrm{NS}}$ \\
$\mathrm{D}$ & & & $0.14^{*}$ & $0.14^{*}$ & $-0.16^{*}$ & $-0.09^{\mathrm{NS}}$ \\
TNS & & & & $0.27^{* *}$ & $-0.02^{\mathrm{NS}}$ & $-0.16^{*}$ \\
NCS & & & & & $-0.02^{\mathrm{NS}}$ & $-0.79^{* *}$ \\
NES & & & & & & $-0.16^{*}$ \\
\hline
\end{tabular}

* (P£0,05); ** (P£0,01); NS (Non significant; $\mathrm{P}>0,05)$.
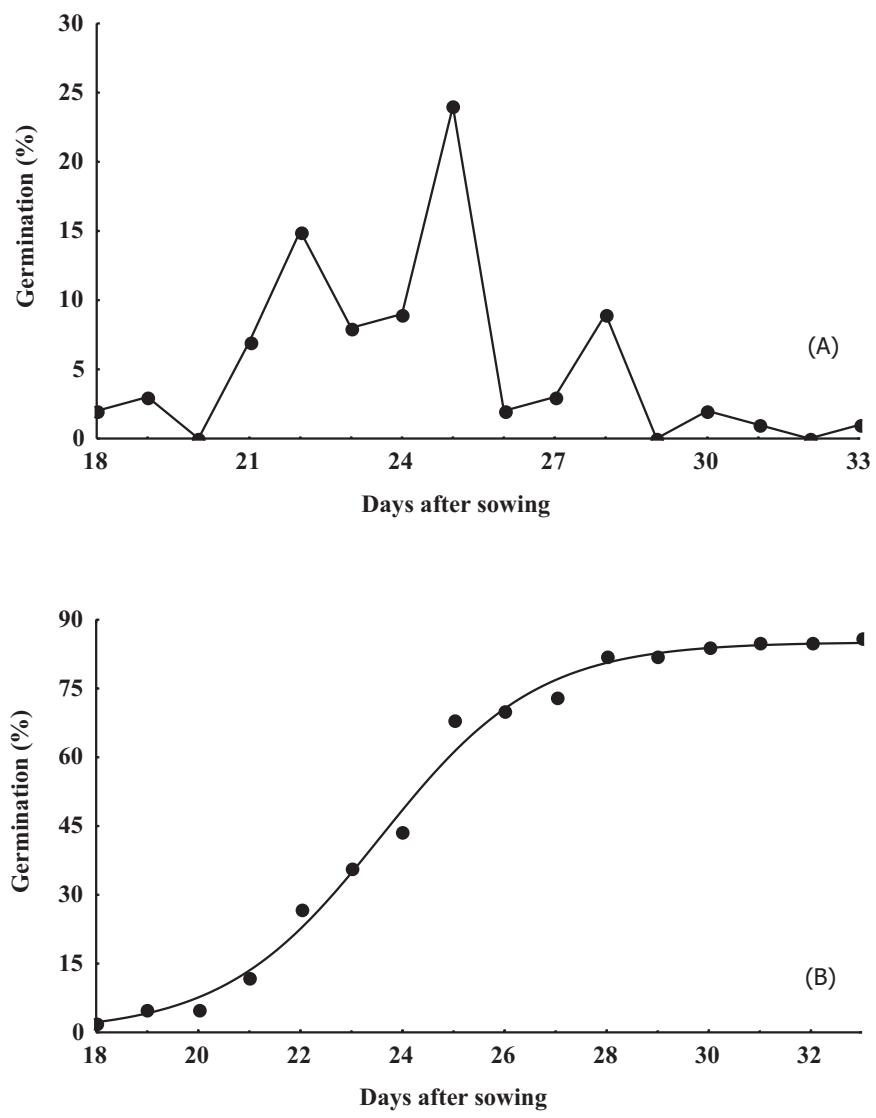

FIGURE 2. Daily (A) and cumulative (B) germination in Pouteria pachycarpa seeds, with $46.2 \%$ of moisture.

percentage of $P$. pachycarpa seeds was similar to the one reported for $P$. caimito (Carvalho et al., 1998; Villachica et al., 1996) and P. sapota (Ricker et al., 2000), and higher than that of P. mallaccensis (Clarke) Baehni (Ng e Sanah, 1979) and P. macrophylla (Pinedo, 1989). Variability on seed germination, common among species of the same genus (Cruz e Simão Neto, 1995) and between accesses of the same species (Cruz et al., 1997), may be caused by dormancy mechanism, seed moisture and genetic characteristics. According to Baskin e Baskin (1998), the germination distributed along the time in recalcitrant species may occur because the water content in the seeds is not sufficient to promote germination or some kind of physiologic dormancy, similar to observed in P. stiptata Cronquist by Garwood (1983).

The percentage of dead seeds and abnormal seedlings was 11 and 3\%, respectively. The number of days to begin the germination was 18.5 days, smaller than observed in $P$. caimito and P. macrophylla according to Villachica et al. (1996) and Pinedo (1989), respectively. The mean germination time was 24.2 days.

\section{CONCLUSIONS}

The samples present great variability on the quantitative characteristics of fruits and seeds. There is a correlation for fruits characteristics (mass and length, mass and diameter and length and diameter) and for seeds (number of complete seeds and number of seeds damaged).

The germination is slow and not uniform.

\section{ACKNOWLEDGEMENTS}

To Moacyr B. Dias-Filho from Embrapa Amazônia Oriental, for providing valuable suggestions to improve this manuscript.

\section{REFERENCES}

ASSOCIAÇÃO DAS INDÚSTRIAS EXPORTADORAS DE MADEIRAS DO ESTADO DO PARÁ. Estatísticas de exportações dos produtos serrados e manufaturados de madeira. Belém; 1998. $7 \mathrm{p}$.

BASKIN, C.C.; BASKIN, J.M. Seeds: ecology, biogeography, and evolution of dormancy and germination. San Diego: Academic Press, 1998. 666p.

BEIGUELMAN, B. Curso prático de bioestatística. 2.ed. Ribeirão Preto: Sociedade Brasileira de Genética, 1991. 231p.

BRASIL. Ministério da Agricultura e Reforma Agrária. Regras para análise de sementes. Brasília: SNDA/DNDV/CLAV, 1992. 365p.

CAMARGOS, J.A.A.; CZARNESKI, C.M.; MEGUERDITCHIAN, I.; OLIVEIRA, D. Catálogo de árvores do Brasil. Brasília: Instituto Brasileiro de Meio Ambiente e dos Recursos Naturais Renováveis. 1996. 887p.

CARVALHO, J.E.U.; NASCIMENTO, W.M.O.; MÜLLER, C.H. 
Características físicas e de germinação de sementes de espécies frutíferas da Amazônia. Belém: Embrapa-CPATU, 1998. 18p. (Boletim de Pesquisa, 203).

CAVALCANTE, P.B. Frutas comestíveis da Amazônia. 5.ed. Belém: Edições CEJUP, 1991. 279p.

CRUZ, E.D.; CARVALHO, J.E.U. Biometria de frutos e sementes e germinação de curupixá (Micropholis cf. venulosa Mart. e Eichler - Sapotaceae). Acta Amazonica, Manaus, v.33, n.3, p.389-398, 2003.

CRUZ, E.D., CARVALHO, J.E.U.; OLIVEIRA, R.P. Variabilidade na germinação e dormência em sementes de Centrosema pubecens Benth. Pasturas Tropicales, Cali, v.19, n.1, p.37-41, 1997.

CRUZ, E.D.; SIMÃO NETO, M. Produção de sementes de Centrosema na região Bragantina, Pará, Brasil. Pasturas Tropicales, Cali, v.17, n.1, p.18-23, 1995.

CZABATOR, F.J. Germination value: an index combining speed and completeness of pine seed germination. Forest Science, Washington, v.8, n.4, p.386-396, 1962.

DUKE, J.A.; POLHILL, R.M. Seedling of Leguminosae. In: POLHILL, R.M.; RAVEN, P.H. (Ed.). Advances in legume systematics. Richmond: Royal Botanical Garden, 1981. v.2, p.941949.

EDMOND, J.B.; DRAPALA, W.J. The effects of temperature, sand and soil, and acetone on germination of okra seeds. Proceedings of the American Society for Horticultural Science, Geneva, v.71, n.5, p.428-434, 1965.

EDWARDS, D.G.W. Forest tree seeds at the end of the $20^{\text {th }}$ century: major accomplishments and needs. IUFRO WORLD CONGRESS, 21., 2000, Kuala Lumpur. Abstract... Kuala Lumpur: International Union of Forestry Research Organization, 2000. v.3, p.54.

GARWOOD, N.C. Seed germination in a seasonal tropical forest in Panama: a community study. Ecological Monograph, Durham, v.53, n.2, p.159-181, 1983.

JAPAN COLOR INSTITUTE. Standard color chart for horticulture plants in Japan. Tokyo: Editorial Committee of Standard Color Chart for Horticulture Plants, 1997.

LOUREIRO, A.A.; FREITAS, J.A.; FREITAS, C.A. Ministério da Ciência e Tecnologia. Essências madeireiras da Amazônia. Manaus: INPA-CPPF, 1997. 112p.
MARTINI, A.; ROSA, N. de A.; UHL, C. Espécies de árvores potencialmente ameaçadas pela atividade madeireira na Amazônia. Belém: AMAZON, 1998. 34p. (Série Amazônia, 11).

NG, F.S.P.; SANAH, M.A. bin N. Germination of fresh seeds of Malaysian trees. The Malaysian Forester, Kuala Lumpur, v.42, n.3, p.221-224, 1979.

PINEDO, M. Evaluación preliminar de la germinación de $\mathbf{2 8}$ frutales tropicales. Lima: INIA, 1989. 40p. (Informe Técnico, 13).

PIRES, J.M.; KOURY, H.M. Estudo de um trecho de mata de várzea próximo a Belém. Belém: IAN, 1958. p.3-44. (Boletim Técnico, 36).

RIBEIRO, J.E.L.S.; HOPKINS, M.J.G.; VICENTINI, A.; SOTHERS, C.A.; COSTA, M.A.S.; BRITO, J.M.; SOUZA, M.A.D.; MARTINS, L.H.P.; LOHMANN, L.G.; ASSUNÇÃO, P.A.C.L.; PEREIRA, E.C.; SILVA, C.F.; MESQUITA, M.R.; PROCÓPIO, L.C. Flora da Reserva Ducke: guia de identificação das plantas vasculares de uma floresta de terra-firme na Amazônia Central. Manaus: INPA, 1999. 799p.

RICKER, M.; SIEBE, C.; SÁNCHEZ B.S.; SHIMADA, K.; LARSON, B.C.; MARTÍNEZ-RAMOS, M.; MONTAGNINI, F. Optimizing seedling management: Pouteria sapota, Diospyros digyna and Cedrela odorata in a Mexican rainforest. Forest Ecology and Management, Amsterdam, v.139, n.1/3, p.63-77, 2000.

SOUZA, M.H.; MAGLIANO, M.M.; CAMARGO, J.A.A. Madeiras tropicais brasileiras. Brasília: Instituto Brasileiro do Meio Ambiente e dos Recursos Renováveis, 1997. 151p.

STATSOFT. Statistic for windows. General conventions and statistical. Statsoft, Tulsa: Inc., 1998

TIPTON, J.L. Evaluation of three growth curve models for germination data analysis. Journal of American Horticultural Science, Mount Vermont, v.109, n.4, p.451-454, 1984.

VAN ROOSMALEM, M.G.M.; GARCIA, O.M.C.G. Fruits of the Amazonian Forest. Part II: Sapotaceae. Acta Amazônica, Manaus, v.30, n.2, p.187-290, 2000.

VÁZQUEZ-YANES, C.; ARÉCHIGA, M.R. Ex situ conservation of tropical rain forest seed: problems and perspectives. Interciencia, Caracas, v.21, n.5, p.293-298, 1996.

VILLACHICA, H.; CARVALHO, J.E.U.; MÜLLER, C.H.; DÍAZ, C.; ALMANZA, M. Frutales y hortalizas promissorios de la Amazonía. Lima: Tratado de Cooperación Amazónica. Secretaria Pro-Tempore, 1996. 367p. (TCA-SPT, 44). 